\title{
REVIEW OF THE FOSSIL TIPHIIDAE, WITH DESCRIPTION OF A NEW SPECIES (HYMENOPTERA)*
}

\author{
By A. P. RASNITSYN \\ Paleontological Institute, \\ Academy of Sciences of the USSR, \\ Profusoyuznaja, 113, 117868, \\ Moscow USSR
}

Through the courtesy of Professor Frank M. Carpenter (Harvard University, Cambridge, Mass.) and Dr. Paul E. S. Whalley (British Museum, Natural History, London, U.K.) I have been able to study the type specimens (good photographs of the specimen in one case) of all described extinct species ever attributed to the Tiphiidae. Five of them have been described as members of the subfamily Anthoboscinae by Cockerell: in 1906 (Lithotiphia scudderi, Geotiphia foxiana), 1910 (G. sternbergi, G. halictina) and 1927 (G. pachysoma); while Hoplisidea kohliana was described originally as a member of the Sphecidae (Cockerell, 1906) and later transferred to the Anthoboscinae by Evans (1966).

From my study of these specimens I have found that the latter species most probably belongs to the Sceliphronini (Sphecidae) and I will treat it elsewhere. The five other species are discussed below and one new species is described. All the species described by Cockerell are from the Lower Oligocene of Florissant, Colorado; the new one is from the ?Upper Oligocene of the Sikhote-Alin Mts., Maritime Province of the USSR. Only the holotypes are known for all these species and each specimen is a female, suggesting a female biased tiphiid population during the Oligocene.

Only two other fossil specimens of Tiphiidae have been mentioned in the literature; both were found in Baltic amber collected by A. Menge and both were identified by Brische (1886) as "Tiphia (?)". Unfortunately, Menge's collection is apparently lost (Heie, 1967, p. 119).

*Manuscript received by the editor August 3, 1985 
The species treated here (figures 1-7) can be assigned to the Tiphiidae on the basis of the strongly fossorial nature of the legs (mid and hind tibiae thick and spiny), combined with the pleisiomorphic wing venation; the latter differs distinctly from that of the Scoliidae, which do have similar fossorial adaptations. In one case (Fig. 2) this indirect evidence is confirmed by the structure of the mesosternum, which shows the pair of lamellae that characteristically partly cover the midcoxae.

The fossil species show a habitus and female wing venation typical for the Anthoboscinae. Nevertheless, they do not belong to that subfamily, mainly because their antennal sockets are overlain with tubercles, clearly seen in one case (Fig. 6) and less clear in another (Fig. 7). There are additional features distinguishing the fossils from Anthoboscinae, viz., flagellum straight or variously bent (Figs. 1, 2, 4,6 ) instead of tightly curled (as in all female Anthoboscinae studied), femora lacking genual plates (Figs. 1-3, 7) or propodeum with longitudinal lines (Figs. 4, 5).

All Tiphiidae with the antennal sockets partly covered by frontal tubercles or ridges belong to the Myzininae and Methochinae. The latter subfamily is not involved here, since its members have thin tibiae bearing only weak spines. [I follow V. Gorbatovsky (personal communication) in treating Pterombrus Smith as a member of the subfamily Methochinae]. Therefore, the Myzininae is the only subfamily with the characters of the fossils and in particular with those of Geotiphia. [Lithotiphia is poorly known but I consider it similar enough to the former genus to classify them together and not to reject Lithotiphia as a tiphiid incertae sedis]. Within the Myzininae the fossils take an isolated position because of the very primitive, male-like wing venation of the females.

Both of these extinct genera can be identified by the following diagnoses. Lithotiphia (Fig. 1): forewing with cu-a cross-vein antefurcal; head capsule with a short oral cavity, distant from occipital carina; hind tibiae very strongly swollen. Geotiphia (Figs. 2-7): fore wing with cu-a interstitial or postfurcal; oral cavity longer, with hypostomae reaching occipital carina; hind tibiae less swollen. The latter genus possibly deserves to be divided into two genera, since sternbergi and pachysoma, in contrast to other species, show mid and/or hind femora with the genual plates, and the propodeum with longitudinal lines. The propodeal structure is unknown in any other 


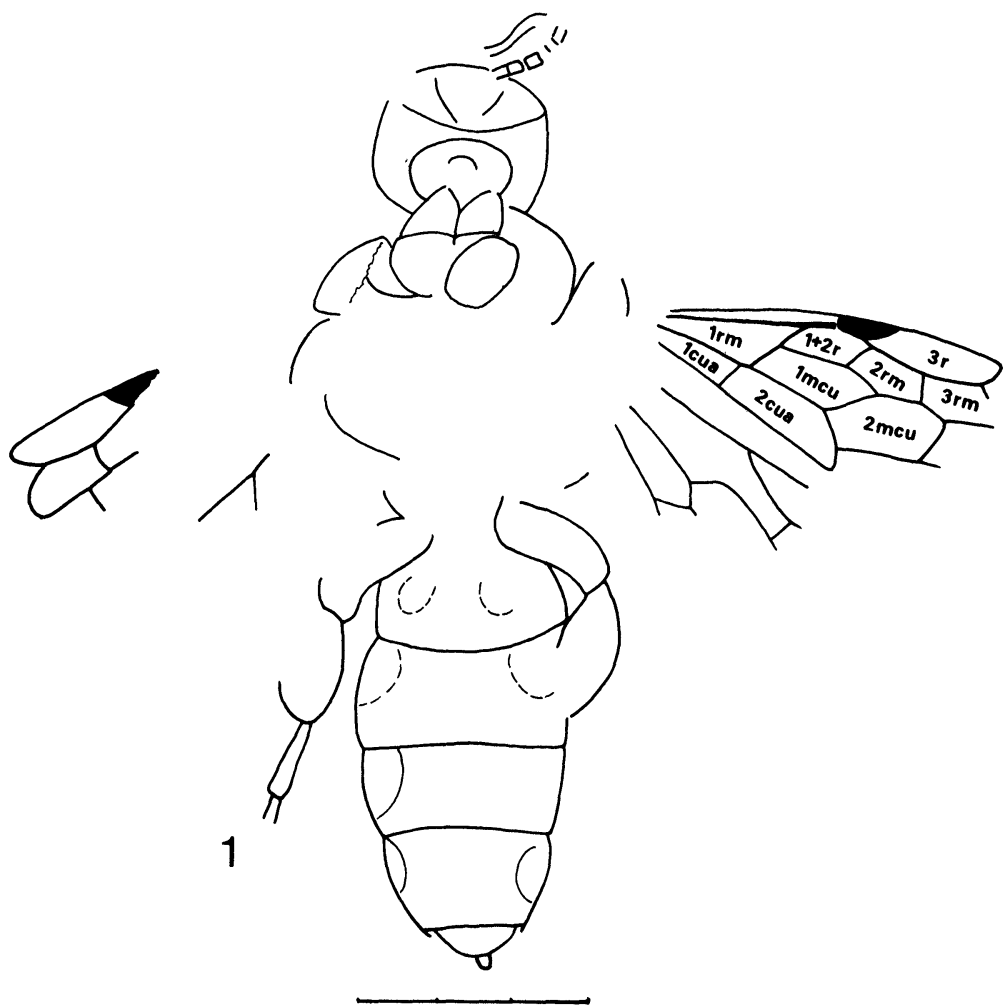

Figure 1. Lithotiphia scudderi Cockerell, holotype, no. 2022, Museum of Comparative Zoology, Harvard University. Wing cells are lettered. Scale line in all figures, $3 \mathrm{~mm}$.

species and I hesitate to create another new genus on a sole character. The following is a descriptive account of the species in these two genera. The details shown in the figures are generally not described below.

\section{Lithotiphia scudderi Cockerell}

Figure 1

Lithotiphia scudderi Cockerell, 1906, p. 51

Body length, $12.3 \mathrm{~mm}$; fore wing length, about $5 \mathrm{~mm}$ (Length is measured here from base to apex of cell $3 r$ ). Gastral terga with light spots. Integumental sculpture not discernible because of covering by Canada balsam. Holotype: M.C.Z. no. 2022. 


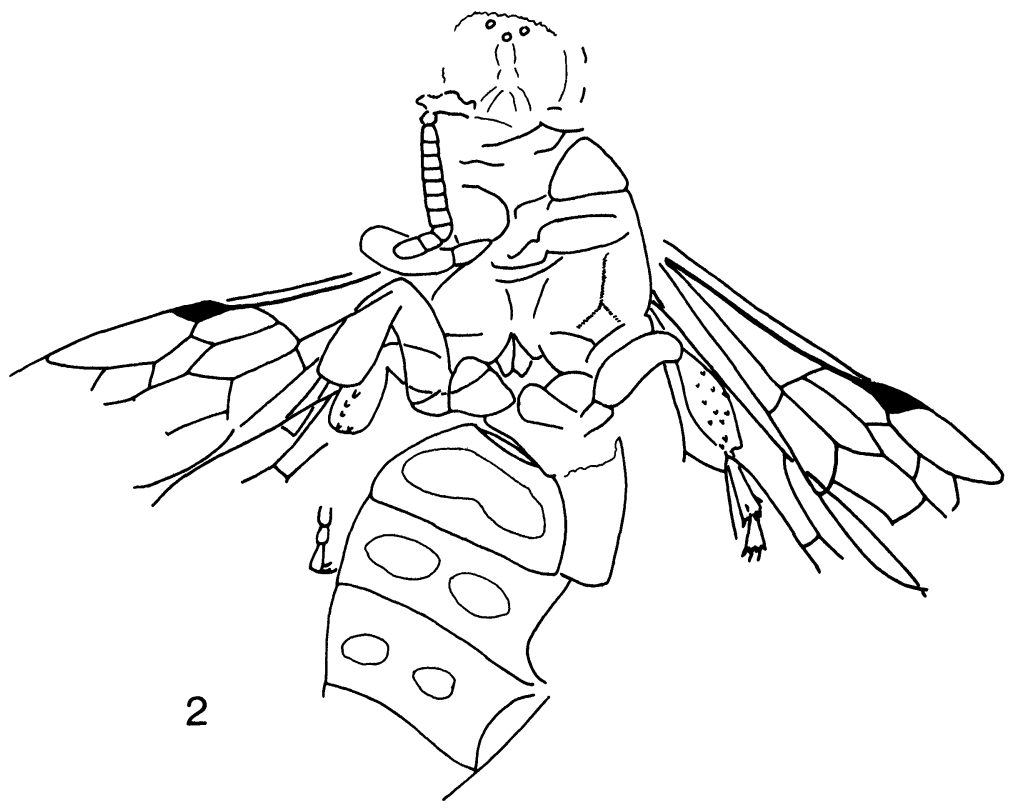

Figure 2. Geotiphia foxiana Cockerell, holotype, no. 2021, Museum of Comparative Zoology, Harvard University.

\section{Geotiphia foxiana Cockerell}

Figure 2

Geotiphia foxiana Cockerell, 1906, p. 52

Body length, as preserved, $11 \mathrm{~mm}$ (probably originally $12 \mathrm{~mm}$.); fore wing length, $6.2 \mathrm{~mm}$. Integumental sculpture not discernible. Ground color moderately dark, the flagellum, tibiae, tarsi, veins, and pterostigma less dark; metasomal sterna with light spots sublaterally, 2nd sternum having the spots large and contiguous. Color pattern of terga unknown. Wing membrane not infumate. Holotype: M.C.Z. no. 2021.

\section{Geotiphia halictina Cockerell \\ Figure 3}

Geotiphia halictina Cockerell, 1910, p. 279

Body length, $18 \mathrm{~mm}$; fore wing length, $3.5 \mathrm{~mm}$. Venation similar to that of foxiana, but differing in smaller size and the position of cell 


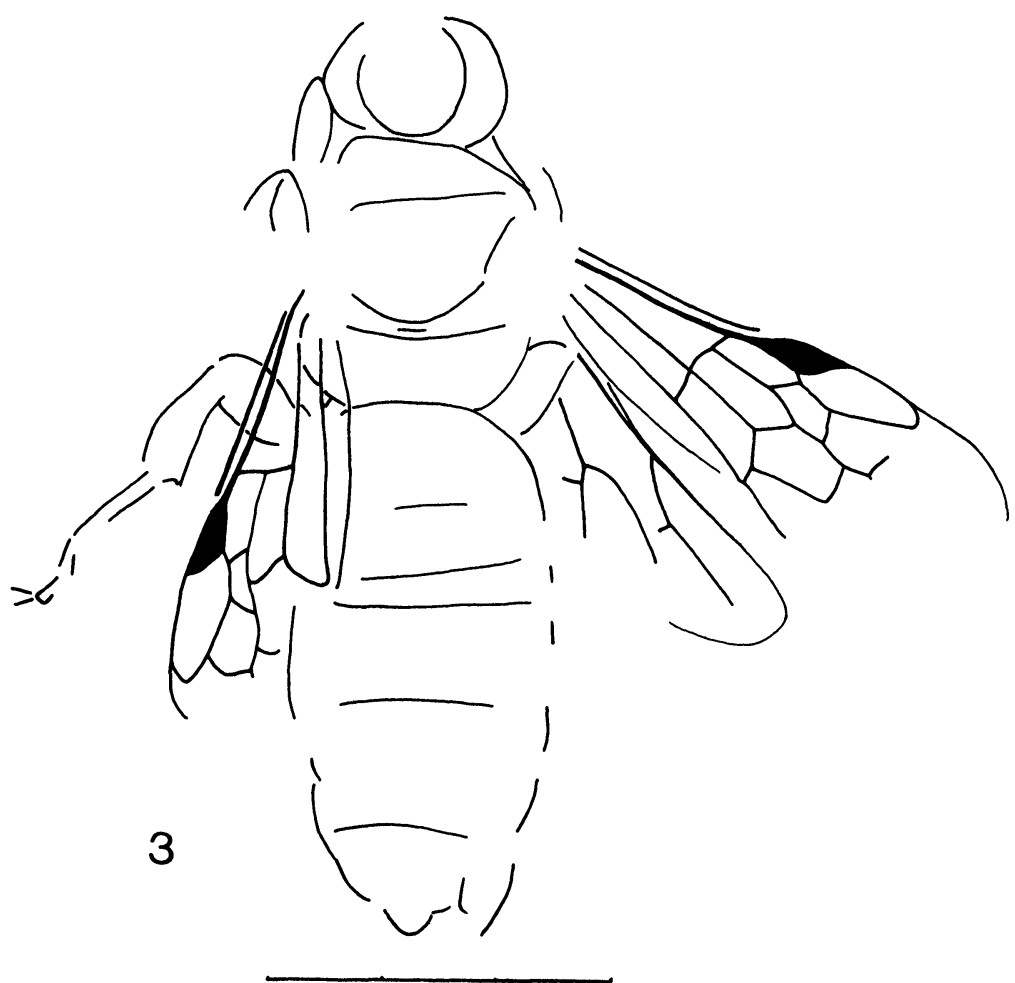

Figure 3. Geotiphia halictina Cockerell, drawing based on photograph of holotype, no. 18619, Museum of the University of Colorado.

$3 \mathrm{r}$ remote from wing margin apically. Integumental sculpture and color pattern unknown. (Description based on photograph of holotype).

\section{Geotiphia sternbergi Cockerell}

Figure 4

Geotiphia sternbergi Cockerell, 1910, p. 277

Body length, $8 \mathrm{~mm}$; fore wing length, $12 \mathrm{~mm}$. Head with posterior surface punctate dorsally and laterally, finely punctatorugose medially. Thorax with distinct, moderately large punctures dorsally; lateral adscutellar depression, metanotum and propodeum finely reticulate. Gastral terga with sculpture fine and sparse, not clear in detail. Ground color dark (not known for fore and mid 


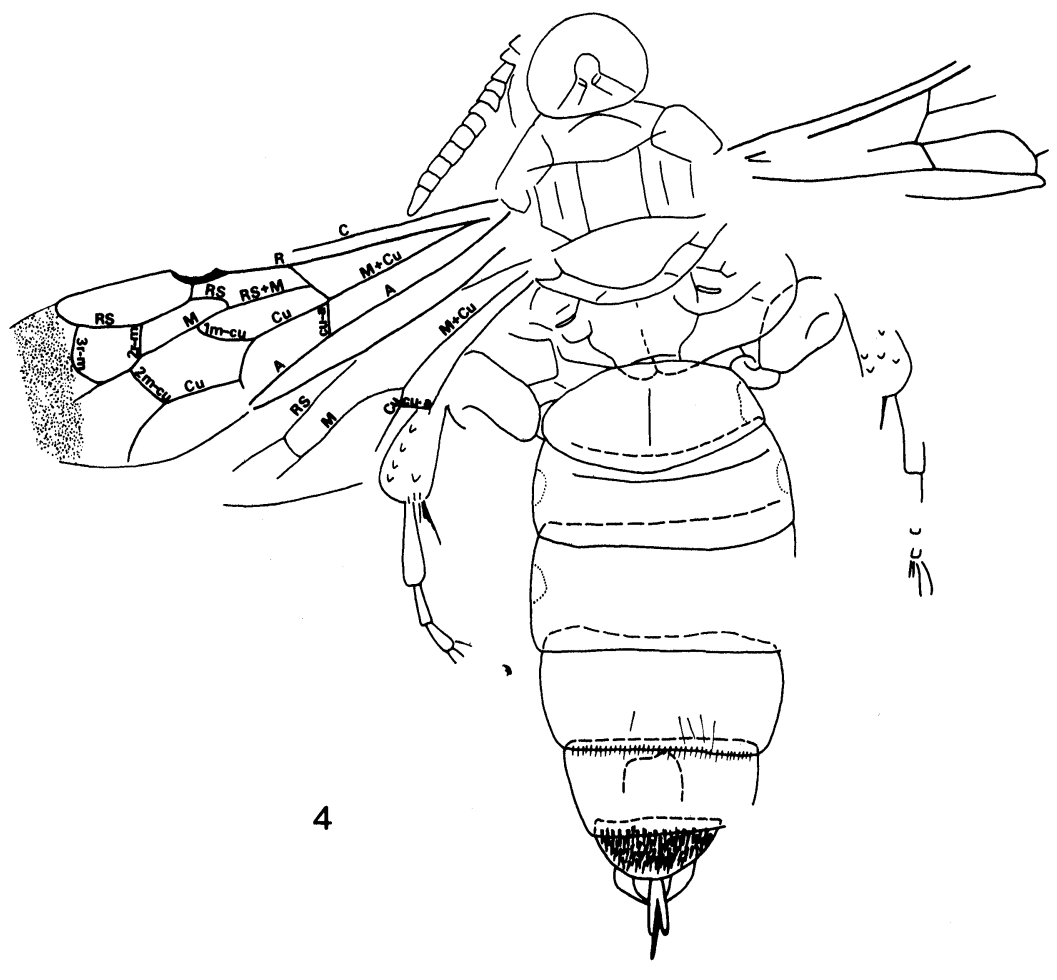

Figure 4. Geotiphia sternbergi Cockerell, holotype, no. 18868, American Museum of Natural History, New York. Wing veins are lettered.

legs), anterior metasomal segments with small light spots laterally. Fore wing apex infumate. Differs from the above species by its large size, modified antennal segments, and in having the hind femur with genual plate; fore wing with cell $2 \mathrm{rm}$ very long, and possibly in having the propodeum with longitudinal lines. Holotype: A.M.N.H., no. 18868 .

\section{Geotiphia pachysoma Cockerell}

Figures 5 and 6

Geotiphia pachysoma Cockerell, 1927, p. 432.

Body length, $9.2 \mathrm{~mm}$; fore wing length, $6.0 \mathrm{~mm}$. Head punctatorugose dorsomedially in part, thorax smooth, with distinct but weak 


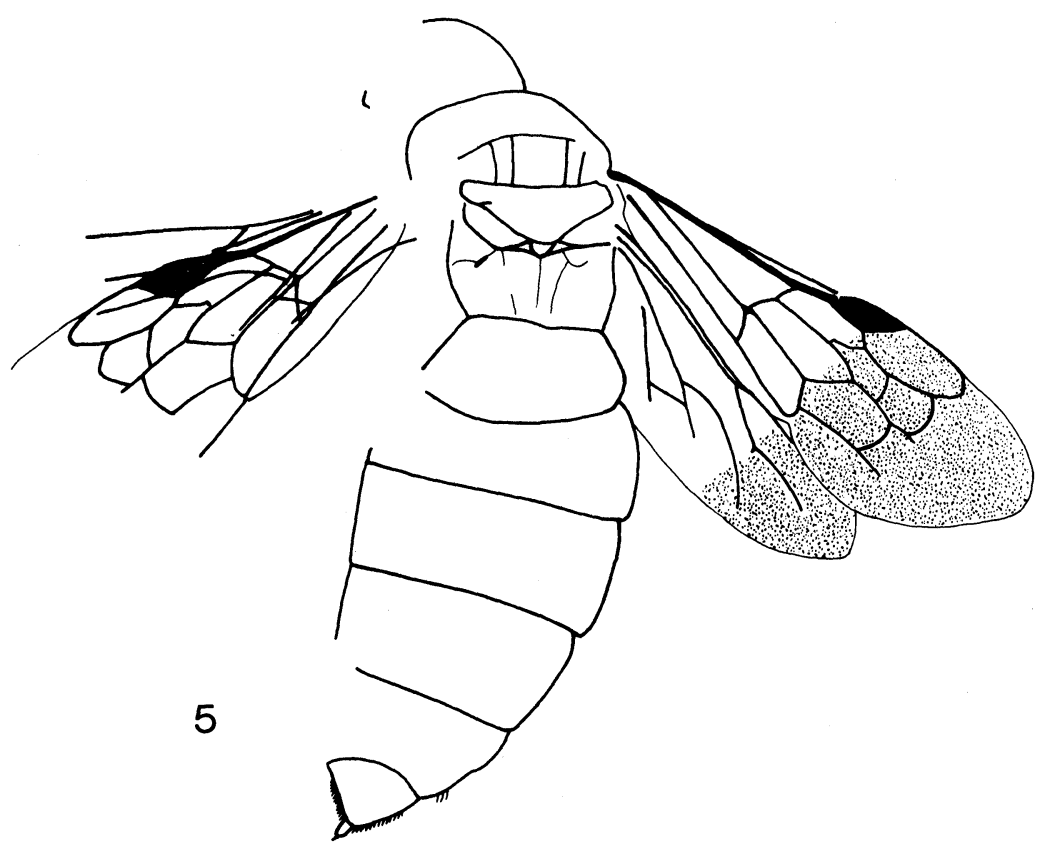

Figure 5. Geotiphia pachysoma Cockerell, holotype, no. In. 26929, British Museum (N.H.), London. Dorsal view.

punctures dorsally; lateral parts of metanotum striate longitudinally. Body with ground color dark, without obvious light spots; wing membrane infumate in apical two-fifths. Similar to sternbergi in having genual plates and dissected propodeum, differing in small size and in having cell $2 \mathrm{rm}$ shorter; genual plates longer. Holotype: B.M. (N.H.), no. In 26929.

\section{Geotiphia orientalis, new species}

Figure 7

Fore wing length about $6 \mathrm{~mm}$. Pterostigma rather long, with 2r-rs arising halfway before apex; cell $3 r$ rounded at costal margin; RS between $\mathrm{RS}+\mathrm{M}$ and $2 \mathrm{r}$-rs almost straight; cells $1 \mathrm{r}$, $2 \mathrm{rm}$ and $3 \mathrm{rm}$ all relatively short; $2 \mathrm{rm}$ and $3 \mathrm{rm}$ of subequal length; $1 \mathrm{~m}$-cu just before the middle of $2 \mathrm{rm} ; 2 \mathrm{~m}-\mathrm{cu}$ at the middle of $3 \mathrm{rm}$, which has the 


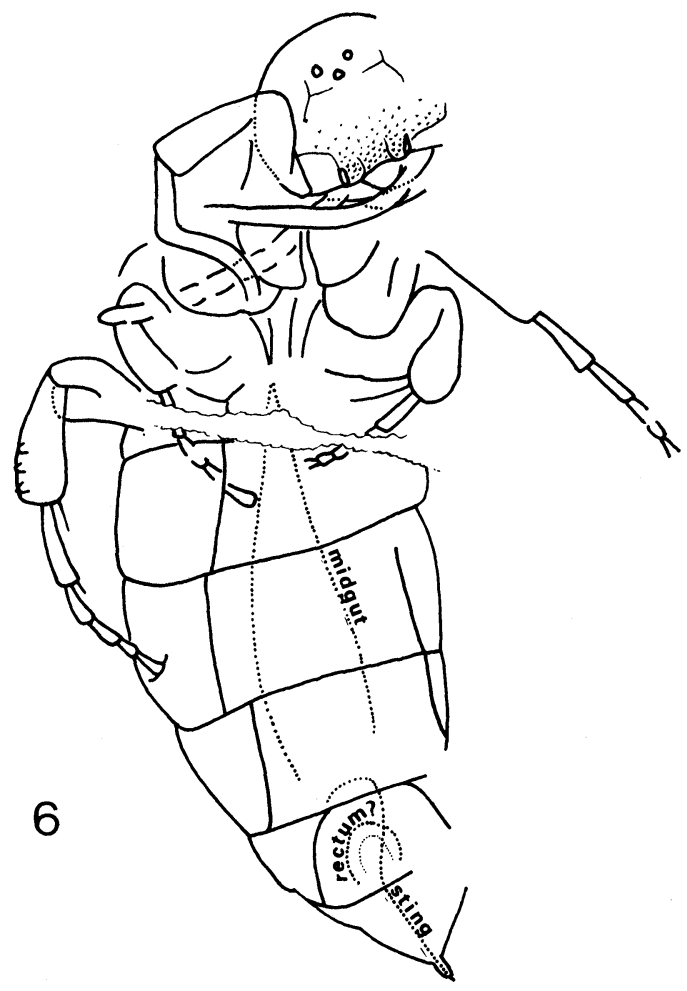

Figure 6. Same as Fig. 5, ventral view.

posterior side very short and the distal side (3r-m) strongly arched; crossvein cu-a at the fork of $\mathrm{M}+\mathrm{Cu}$; posterior genual plates absent on mid and hind femora. Surface sculpturing indistinct. Body structure as preserved lacks taxonomically important features, the details in part difficult to interpret. Ground color moderately dark; tibiae, tarsi, venation, pterostigma, and metasomal segments 2 and 3 less dark and without light spots (subsequent segments not preserved). Wing membrane not infumate.

Holotype (only specimen known): no. 3429/100, Paleontological Institute, Moscow, USSR; collected at Bolshya Svetlovodnaya River, Pozharsky District, Maritime Province, USSR: ?Upper Oligocene. 


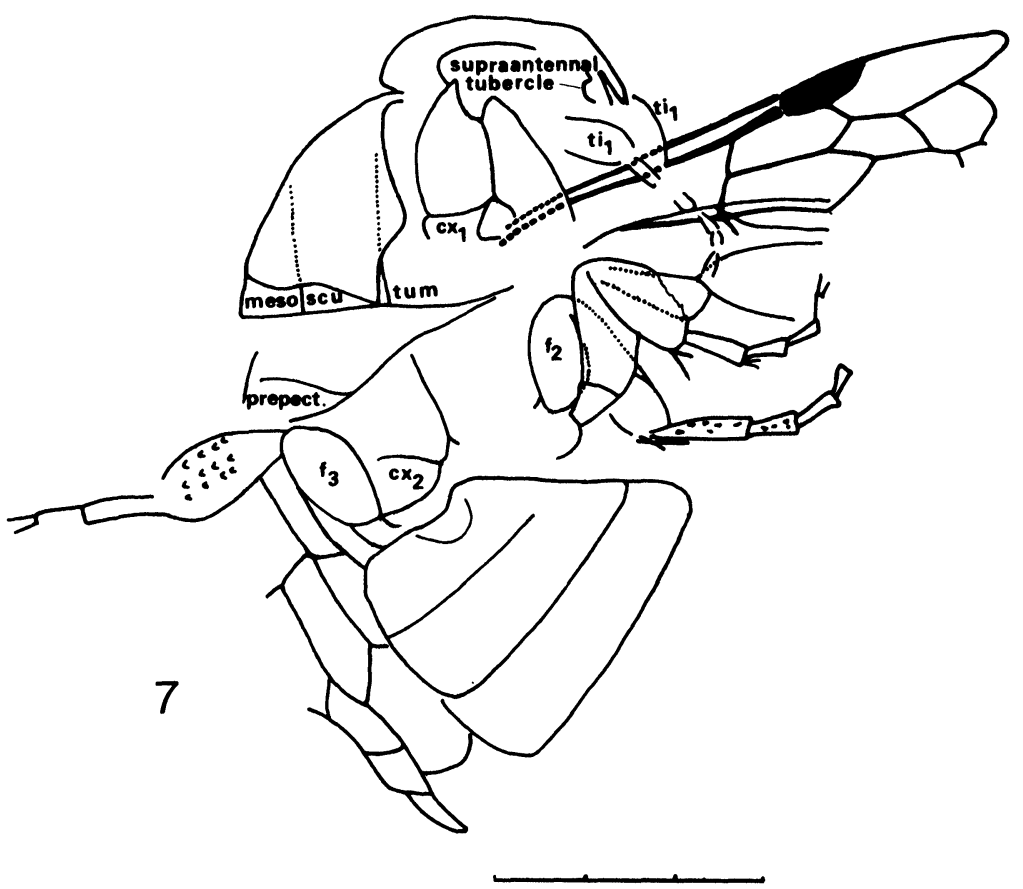

Figure 7. Geotiphia orientalis, holotype, no. 3429/100. Paleontol. Inst. Acad. Sciences, USSR, Moscow.

Comparison. As preserved this species is very similar to foxiana, differing in having a longer pterostigma, the posterior side of cell $3 \mathrm{rm}$ shorter, and the metasomal segments without light spots [The latter difference may be meaningless because the color pattern is known only for the metasonal sterna in foxiana and possibly only for terga in orientalis].

The above data show considerable taxonomic and anagenetic evolution of the subfamily Myzininae since the early Oligocene, an interval of about 35 million years. Both fossil genera have been replaced with a wide array of living genera, and even the most primitive modern genus, Myzinum Latreille, is probably further away from its Oligocene predecessors than these predecessors are from their anthoboscine ancestor. A paleontological history is not 
known for any living myzinine genera, probably because of their preference for environments unfavorable to fossilization (xeric biotopes or, in the case of Hylomesa, tropical forests), but all of them can be easily derived from Geotiphia morphologically (but not from Lithotiphia, because of the apomorphic position of the cu-a crossvein). Geotiphia can be characterized in short as an anthoboscine with supraantennal tubercles, a position not consistent with the current phylogenetic scheme showing synapomorphies for all Tiphiidae other than Anthoboscinae and additional synapomorphies for all Tiphiidae except Anthoboscinae and Thynninae (Brothers, 1975). An alternative scheme with Myzininae independent of other subfamilies (excluding Anthoboscinae and probably Metochinae) seems to me more realistic.

The paleontological records indicate the minimal age of the Myzininae as Early Oligocene. The records seem too scanty, however, to help in identifying the geographic area where the subfamily arose.

\section{SUMMARY}

Types of the previously described fossil Tiphiidae are studied. Two genera and six species are recognized, each species known only from the holotype: Lithotiphia Cockerell, with only one species, scudderi Cockerell; and Geotiphia Cockerell, with foxiana Cockerell (type-species), halictina Cockerell, orientalis, n.sp., sternbergi Cockerell, and pachysoma Cockerell. The fossils are found to represent the most primitive members of the subfamily Myzininae, indicating that the subfamily originated from the Anthoboscinae independently of the Thynninae, Tiphiinae, and Brachycistidinae. Hoplisidea kohliana Cockerell is now determined as belonging to the Sceliphronini of the family Sphecidae and will be treated elsewhere. All species mentioned are from the Lower Oligocene of Florissant, Colorado, except the new one, G. orientalis, which is from the ?Upper Oligocene of Sikhote-Alin Mts., Maritime Province of USSR. 


\section{Literature Cited}

BRISCHKE, D.

1886. Die Hymenopteren des Bernsteins. Schrift. naturf. Gesellsch. Danzig, n.f., 6: 278-279.

BROTHERS, D. J.

1975. Phylogeny and classification of the Aculeate Hymenoptera, with special reference to Mutillidae. Univ. Kansas Sci. Bull., 50(11): 483-648.

Cockerell, T. D. A.

1906. Fossil Hymenoptera from Florissant, Colorado. Bull. Mus. Comp. Zoology, Harvard Univ., 50: 33-58.

1910. Fossil insects and a crustacean from Florissant, Colorado. Bull. Amer. Mus. Nat. Hist., 28: 275-288.

1927. Hymenoptera and a caddis larva from the Miocene of Colorado. Ann. Mag. Nat. Hist., (9)20: 429-435.

Evans, H. E.

1966. The comparative ethology and evolution of the sand wasps. Harvard Univ. Press, Cambridge, Mass., p. 1-526.

HeIE, O.

1967. Studies on fossil aphids (Homoptera, Aphidodea). Spol. Zool. Mus. Hauniensis, 26: 1-274. 

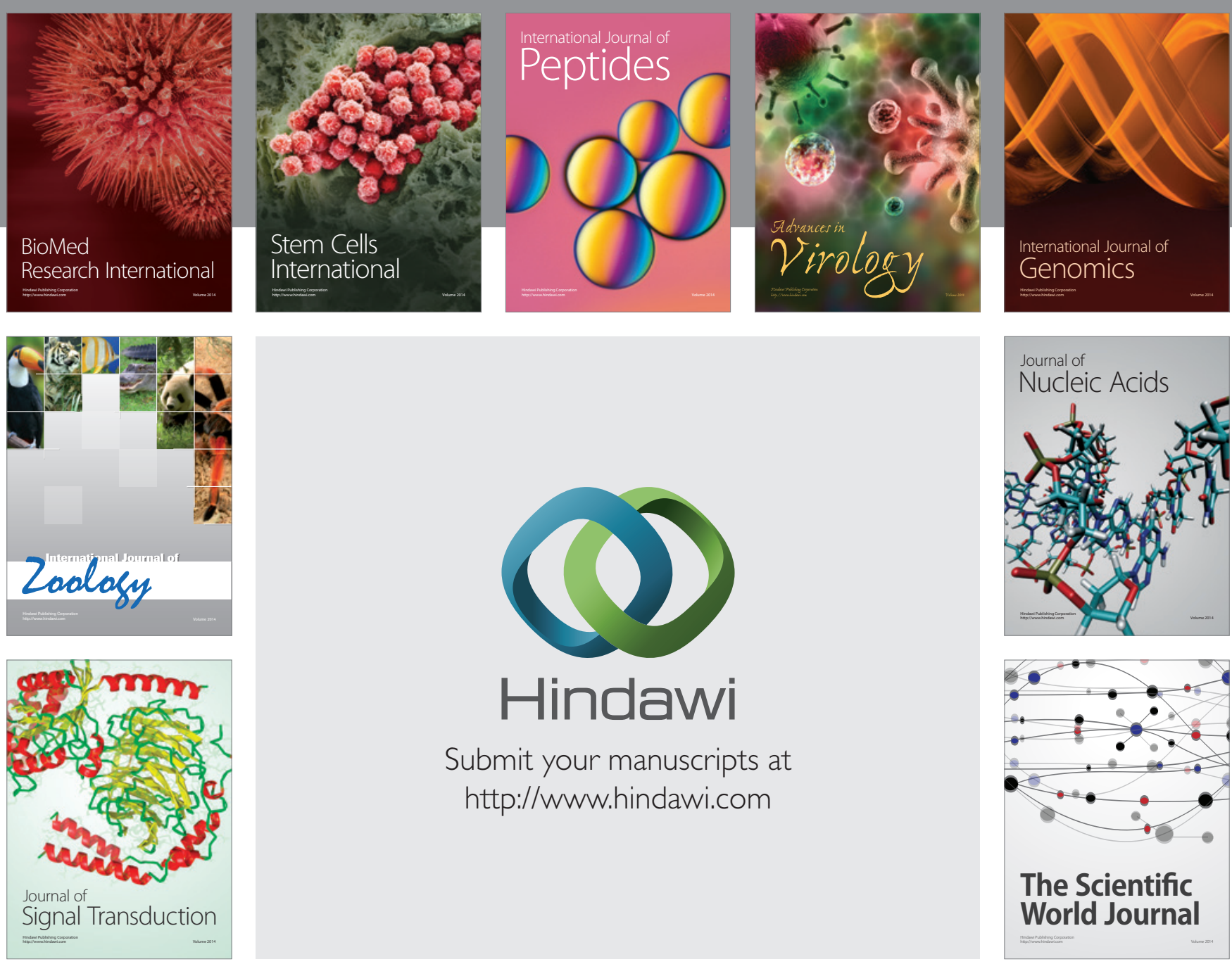

Submit your manuscripts at

http://www.hindawi.com
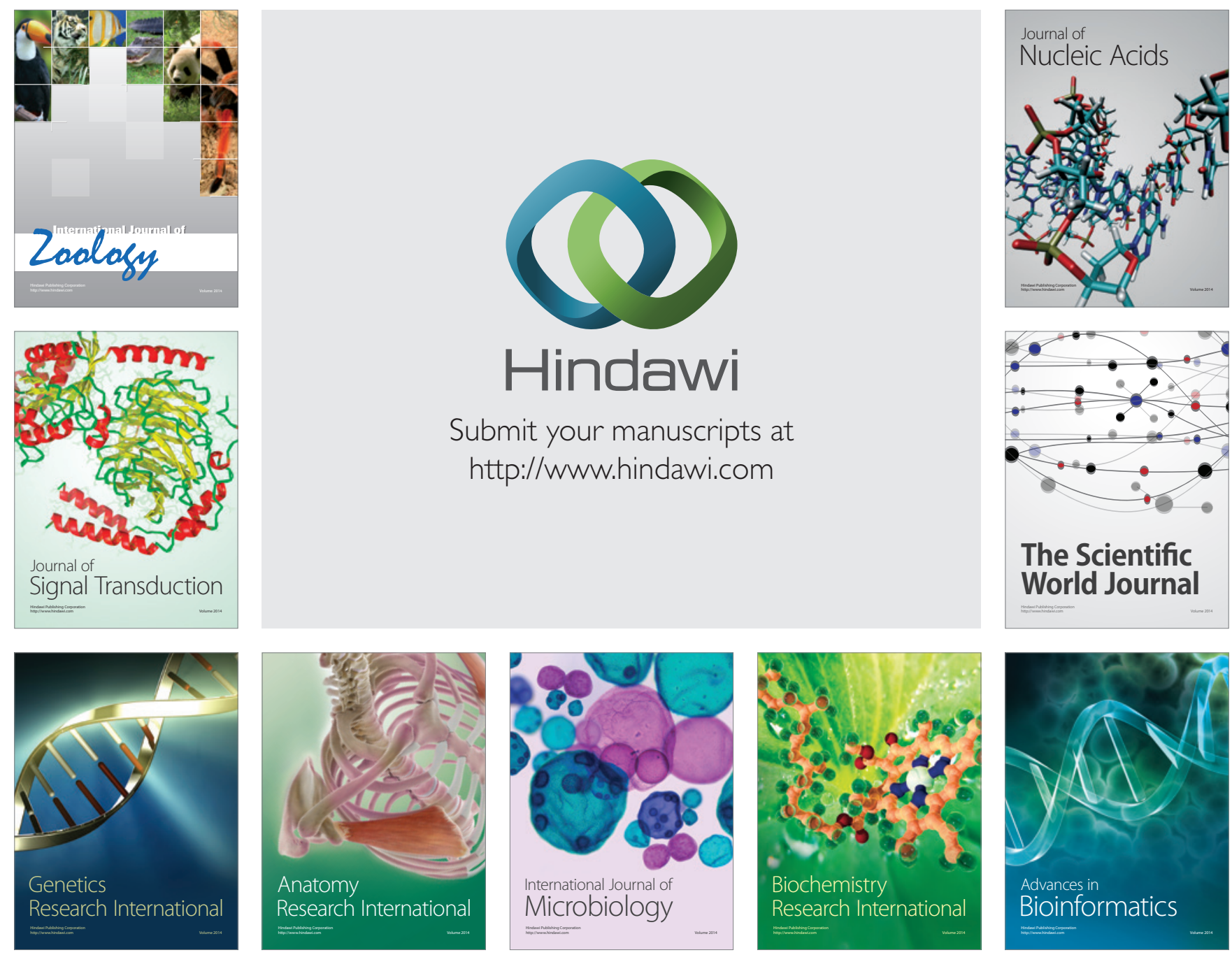

The Scientific World Journal
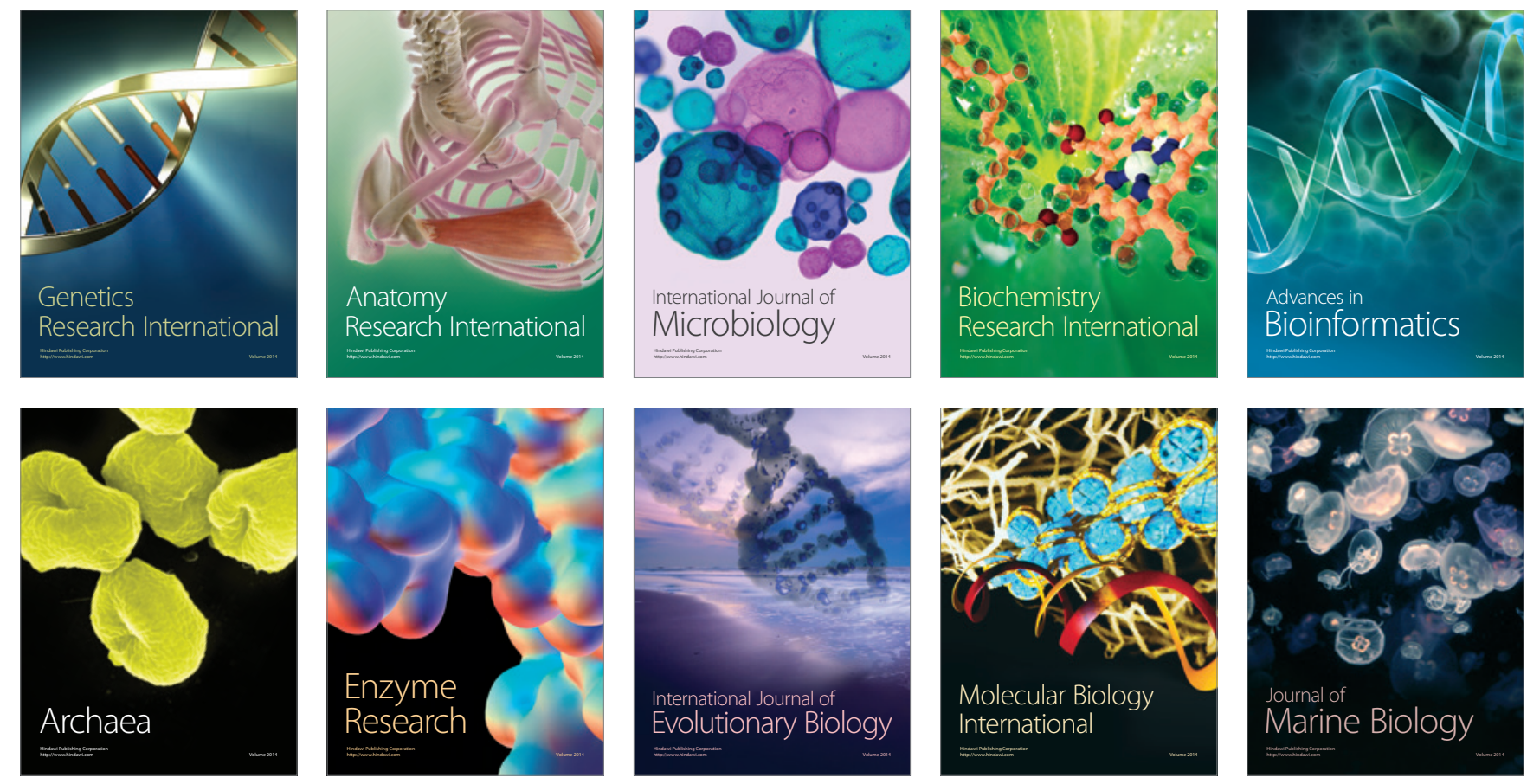